\title{
Harnessing molasses as a low-cost carbon source for production of poly- hydroxy butyrate (PHB) using Burkholderia sp. B73 bacteria
}

\author{
Pemanfaatan molase sebagai sumber karbon murah untuk produksi poli hidroksi butirat (PHB) dengan \\ menggunakan bakteri Burkholderia sp. B73 \\ Diah RATNANINGRUM ${ }^{\left.1)^{*}\right)}$, Een Sri ENDAH ${ }^{1)}$, Puspita LISDIYANTI'), Sri PRIATNI ${ }^{1)} \&$ Vienna \\ SARASWATY ${ }^{1)}$
}

\author{
${ }^{1)}$ Research Unit for Clean Technology, LIPI, Jl. Cisitu Sangkuriang, Bandung 40135, Indonesia \\ ${ }^{2}$ Research Centre for Biotechnology, LIPI, Jl. Raya Bogor Km 46, Cibinong, Bogor 16911, Indonesia
}

Received 1 May 2021/ Accepted 25 October 2021

\begin{abstract}
Abstrak
Burkholderia sp. telah dilaporkan sebagai penghasil poli-hidroksi butirat (PHB). PHB adalah poliester alami yang telah dimanfaatkan secara luas untuk pangan, obat dan biomedis. Akan tetapi, biaya produksi PHB yang tinggi menyebabkan PHB kurang dimanfaatkan. Molase, produk samping industri gula tebu yang tersedia dalam jumlah banyak, dapat dimanfaatkan sebagai pengganti sumber karbon untuk produksi PHB. Penelitian ini bertujuan untuk mengevaluasi produksi $P H B$ dengan menggunakan bakteri Burkholderia sp. B73 dalam media fermentasi yang mengandung molase sebagai sumber karbon alternatif. Eksperimen skala laboratorium dilakukan dengan menggunakan labu Erlenmeyer pada shaker kecepatan $150 \mathrm{rpm}$ dan suhu $30^{\circ} \mathrm{C}$ untuk mengetahui rasio $C / N$ terbaik dalam mengakumulasi biomassa dan produksi PHB. Parameter yang diamati adalah pertumbuhan mikroba, berat sel kering dan rendemen PHB, serta spektrum FTIR. Hasil penelitian menunjukkan bahwa molase dapat dimanfaatkan untuk menumbuhkan Burkholderia sp. B73 dan kadar PHB tertinggi diperoleh dengan menggunakan molase dalam medium fermentasi pada rasio C/N 20:1. Selain itu, dengan mengatur pH menjadi 7.0 sebelum fermentasi, produksi PHB tertinggi juga dicapai. Lebih penting lagi, dengan menggunakan molase sebagai sumber karbon, rendemen PHB yang diperoleh 2 kali lipat lebih tinggi dibandingkan dengan menggunakan medium sintetik Ramsay pada penelitian kami sebelumnya. Sebagai kesimpulan, pada penelitian ini dibuktikan bahwa molase dapat digunakan sebagai sumber karbon yang murah untuk produksi $P H B$ dengan menggunakan bakteri Burkholderia sp. B73.
\end{abstract}

[Kata kunci: C/N, rasio, gula tebu]

\footnotetext{
*) Correspondence author: nandyah@gmail.com
}

\begin{abstract}
Burkholderia sp. has been reported as a polyhydroxy-butyrate (PHB) producer. $\mathrm{PHB}$ is a natural polyester class with a wide range of applications in foods, medicines, and biomedicines. However, the high production cost of PHB may limit its potential. Molasses, a byproduct of the sugarcane industry available abundantly, may be used as an alternative carbon source of PHB production. In this research, we aimed to evaluate $\mathrm{PHB}$ production by Burkholderia sp. B73 in fermentation media using molasses as an alternative carbon source. Smallscale experiments were performed in Erlenmeyer flasks on a shaker at $150 \mathrm{rpm}$ and $30^{\circ} \mathrm{C}$ to evaluate the best initial $\mathrm{C} / \mathrm{N}$ ratio for biomass accumulation and $\mathrm{PHB}$ production. A set of parameters including bacterial growth, dry cell weight, yield, and FTIR spectrum of PHB were observed. The results showed that molasses could be used to grow Burkholderia sp. B73 and the highest PHB production was obtained when a $20: 1 \mathrm{C} / \mathrm{N}$ ratio of molasses was applied in the fermentation medium. In addition, when the initial $\mathrm{pH}$ was adjusted to 7.0, the highest PHB yield was also produced. More importantly, the use of molasses as a carbon source improved the PHB yield by nearly 2-fold compared with our previous report using a synthetic Ramsay's minimal medium. In conclusion, the experiment results showed that molasses could be used as a low-cost carbon source for PHB production by Burkholderia sp. B73 bacteria.
\end{abstract}

[Keywords: C/N; ratio; sugarcane]

\section{Introduction}

Plastics are essential for food packaging (Accorsi et al., 2014). Currently, the plastics used for food packaging are generally derived from petrochemicals, which are very difficult to degrade (Webb et al., 2013). Poly $\beta$-hydroxybutyric acid 
(PHB) is a natural polyester produced and accumulated intracellularly in Gram-positive and Gram-negative bacteria (Sudesh et al., 2000). The physical characteristics of PHB, including molecular weight, brittleness, melting point, and glass temperature, are similar to those of some of the common petrochemical-derived plastic (Sudesh et al., 2000; Luo et al., 2014). The major advantage of PHB is that it is fully degradable (Sudesh et al., 2000; Koller, 2017). Accordingly, PHB has promising application potential in materials science, food, biomedicine, medicine, etc., due to its eco-friendly nature.

The main challenge for the commercialization of PHB is its high production cost compared to petroleum-derived plastics (Choi \& Lee, 1999). To date, much effort has been focused on reducing the production cost of $\mathrm{PHB}$ by using different strategies, including screening high potential bacterial strains and optimization of the fermentation procedure and the recovery process (Mostafa et al., 2018). Studies regarding the production of PHB suggest that the main contributor to the high production cost of $\mathrm{PHB}$ is the high cost of carbon substrate, making it 5-fold more costly than the production of petroleumderived plastics. In essence, the carbon source selection is the critical aspect in reducing the total cost of the PHB final product (Kamravamanesh et $a l ., 2018)$. Thus, the optimal approach is to select a sustainable, economical, and readily available carbon substrate for bacterial growth and efficient PHB production.

Molasses, a by-product of the sugarcane industry, is a potential carbon source (Chauhan et al., 2011). One $\mathrm{kg}$ of sugar produces nearly $0.3 \mathrm{~kg}$ of molasses, making this by-product abundantly available (Botha \& von Blottnitz, 2006). As a byproduct, molasses is responsible for water and air pollutions, i.e., brown water, bad smell, forming sludge, and breeding site for mosquitos and flies if not taken advantage of and properly processed (Chauhan et al., 2011). However, molasses contains high concentrations of sucrose, fructose, glucose, raffinose, reducing sugar as well as carbohydrates, making it a promising alternative carbon source for fermentation (Yan et al., 2011), where the content of sugar and organic materials in it are the main target in production of PHB. Studies have reported successful production of PHB by Bacillus sp Jma5 (Wu et al., 2001), Bacillus subtilis, Escherichia coli (Gomaa, 2014), Alcaligens eutrophus (Beaulieu et al., 1995), and Enterobacter sp. SEL2 (Naheed \& Jamil, 2014) used molasses as a carbon source; the resulting PHB yield ranged from 17 to $88 \%(\mathrm{w} / \mathrm{w})$. Hence, the utilization of molasses has benefits that are not limited to its potency as a carbon source but can also to help solving environmental problems.

Burkholderia sp. has been reported for the first time to produce a relatively high amount of
PHB in synthetic media compared with other polyhydroxyalkanoates (PHA)-producing bacteria (Ratnaningrum et al., 2019). However, the effect of utilizing molasses for the production of PHB by Burkholderia sp. B73 has not been reported yet. In this paper, we observed the potency of molasses for the growth of Burkholderia sp. B73 and production of $\mathrm{PHB}$ using various $\mathrm{C} / \mathrm{N}$ ratios. In addition, the effect of initial $\mathrm{pH}$ in the fermentation medium containing molasses for PHB production was also evaluated.

\section{Materials and Methods}

\section{Microorganism and sub-culture conditions}

Burkholderia sp B73 used in this study was obtained from the collection of the Research Center for Biotechnology, Indonesian Institute of Sciences, Cibinong-Indonesia. The strain was regenerated in a nutrient agar (NA) slant $\left(30^{\circ} \mathrm{C}, 24 \mathrm{~h}\right)$. The fresh inoculum was then transferred to nutrient broth (NB) medium containing beef extract $0.3 \% \mathrm{w} / \mathrm{v}$ and peptone $0.5 \% \mathrm{w} / \mathrm{v}$ with the addition of sodium chloride $0.8 \% \mathrm{w} / \mathrm{v}$ and incubated in a shaker incubator $\left(150 \mathrm{rpm}, 30{ }^{\circ} \mathrm{C}, 24 \mathrm{~h}\right)$. After $24 \mathrm{~h}$ of cultivation, the starter culture containing $1.5 \times 10^{6}$ viable cells $/ \mathrm{mL}$ of Burkholderia sp. B73 was inoculated in the fermentation medium containing molasses.

Confirmation of Burkholderia sp. B73 as $P H B$
producing bacteria

The confirmation of Burkholderia sp. B73 as PHB-producing bacteria has been done in previous research (Ratnaningrum et al., 2019). PHBproducing bacteria were observed based on Bhuwal et al. (2013) and Spiekermann et al. (1999) methods. Burkholderia sp. B73 was inoculated in the nutrient agar (NA) containing Nile Red. After Nile Red staining showed bright pink to orange fluorescence under irradiation with UV light, and the fluorescent was observed under a fluorescence microscope at $\lambda$ $540 \mathrm{~nm}$.

\section{Pre-treatment of molasses}

About $500 \mathrm{~g}$ locally collected molasses (Cirebon, West Java, Indonesia) were mixed with $500 \mathrm{~mL}$ of distilled water and added $3 \mathrm{~mL}$ $\mathrm{K} 4 \mathrm{Fe}(\mathrm{CN}) 6.3 \mathrm{H} 2 \mathrm{O}$ to remove heavy metals and other inhibitors. The mixture was heated at $70{ }^{\circ} \mathrm{C}$ for 30 min and stored overnight. The mixture was then centrifuged (7000 rpm, $15 \mathrm{~min}$ ), and the supernatant was collected and used as a carbon source/substrate for further process (Ashraf et al., 2015).

\section{Preparation of fermentation medium containing molasses}

Fermentation media containing molasses at $\mathrm{C} / \mathrm{N}$ ratios of $5: 1,15: 1$, and $20: 1$ were prepared by adding molasses at 5,15 , and $20 \mathrm{~g} \mathrm{~L}^{-1}$ into a mixture 
of Ramsay minimal media of $17 \mathrm{~g} \mathrm{~L}^{-1}\left(\mathrm{NH}_{4}\right)_{2} \mathrm{HPO}_{4}$, $10 \mathrm{~mL} \mathrm{MgSO}_{4} .7 \mathrm{H}_{2} \mathrm{O} 0.1 \mathrm{M}, 3.7 \mathrm{~g} \mathrm{~L}^{-1} \mathrm{KH}_{2} \mathrm{PO}_{4} .7 \mathrm{H}_{2} \mathrm{O}$, $5.8 \mathrm{~g} \mathrm{~L}^{-1} \mathrm{~K}_{2} \mathrm{HPO}_{4}$, trace element solution containing $0.0278 \mathrm{~g} \mathrm{~L}^{-1} \mathrm{FeO}_{4} .7 \mathrm{H}_{2} \mathrm{O}, 0.0198 \mathrm{~g} \mathrm{~L}^{-1} \mathrm{MnCl}_{2} .4 \mathrm{H}_{2} \mathrm{O}$, $0.0281 \mathrm{~g} \mathrm{~L}^{-1} \mathrm{CoSO}_{4} .7 \mathrm{H}_{2} \mathrm{O}, 0.0167 \mathrm{~g} \mathrm{~L}^{-1} \mathrm{CaCl}_{2} .7 \mathrm{H}_{2} \mathrm{O}$, $0.0017 \mathrm{~g} \mathrm{~L} \mathrm{~L}^{-1} \mathrm{CuCl}_{2} .2 \mathrm{H}_{2} \mathrm{O}$ and $0.0029 \mathrm{~g} \mathrm{~L}^{-1}$ $\mathrm{ZnSO}_{4} .7 \mathrm{H}_{2} \mathrm{O}$. The mixture was sterilized in an autoclave (at $121^{\circ} \mathrm{C}, 1 \mathrm{~atm}$ for $15 \mathrm{~min}$ ) and kept at ambient temperature before fermentation.

\section{Production of $P H B$}

The production of PHB was conducted at a labscale by using a $500 \mathrm{~mL}$ Erlenmeyer flask containing $100 \mathrm{~mL}$ of fermentation medium. The fermentation process of PHB production was conducted in a shaker incubator $\left(150 \mathrm{rpm}, 30^{\circ} \mathrm{C}\right.$ for $\left.72 \mathrm{~h}\right)$.

Effect of molasses as a carbon source on the growth of Burkholderia sp. B73

Molasses at various $\mathrm{C} / \mathrm{N}$ ratios 5:1, 15:1 and 20:1 were added into the fermentation medium for Burkholderia sp. B73 cultivation. The supernatant of the fermentation medium was collected for reducing sugar analysis, whereas the bacterial cells were collected for dry cell weight determination.

\section{Dry cell weight determination}

The dry cell weight (DCW) of Burkholderia sp. B73 was determined by gravimetry analysis. Ten $\mathrm{mL}$ of culture sample was centrifuged at $7000 \mathrm{rpm}$ for 15 min to separate cells and supernatant. The pellets obtained were washed twice with $5 \mathrm{~mL}$ of distilled water. This procedure was repeated two times. After washing, the cell pellets were suspended in $10 \mathrm{~mL}$ of distilled water. About $1 \mathrm{~mL}$ of cell suspension was transferred into a falcon tube for gravimetric analysis (Aramvash et al., 2018). Three independent replications were performed.

\section{Extraction and quantification of PHB yield}

The extraction of the PHB produced was conducted according to Kresnawaty et al. (2016) with a slight modification. Ten $\mathrm{mL}$ of cell culture suspension was centrifugated at $7000 \mathrm{rpm}$ for $15 \mathrm{~min}$. The supernatant was collected for reducing sugar analysis, and the cell pellets were suspended in $10 \mathrm{~mL}$ distilled water. One $\mathrm{mL}$ of cell suspension was processed for cell lysis. The cell suspension was mixed with $1 \mathrm{~mL}$ of natrium hypochlorite $5 \% \mathrm{v} / \mathrm{v}$ and $3 \mathrm{~mL}$ of $0.1 \mathrm{M} \mathrm{pH} 7.0$ phosphate buffer for the cell lysis. The mixture was shaken at $180 \mathrm{rpm}$ for $24 \mathrm{~h}$ (RT). The cell lysis was stopped after $24 \mathrm{~h}$, and the supernatant was removed by centrifugation at 7000 $\mathrm{rpm}$ for $15 \mathrm{~min}$. The pellets obtained were washed with $5 \mathrm{~mL}$ of distilled water, $3 \mathrm{~mL}$ of acetone, and 3 $\mathrm{mL}$ of diethyl ether, respectively. The PHB obtained was then dried in an oven blower $\left(70^{\circ} \mathrm{C}\right)$ until constant weight.
The yield of PHB was calculated with the following formula:

$$
\begin{aligned}
& \text { The yield of PHB (\%) } \\
& =\frac{\text { dry weight of extracted PHB }(\mathrm{g} / \mathrm{L})}{\text { dry cell weight }(\mathrm{g} / \mathrm{L})} \times 100 \%
\end{aligned}
$$

\section{Reducing sugar analysis}

The concentration of reducing sugar in the fermentation medium was analyzed according to the Nelson Somogy method. One $\mathrm{mL}$ of sample was added to a test tube and mixed with $1 \mathrm{~mL}$ NelsonSomogy reagent $(25 \mathrm{~mL}$ of Nelson A and $1 \mathrm{~mL}$ of Nelson B solution). The mixture was incubated for $20 \mathrm{~min}$ at $100^{\circ} \mathrm{C}$ in a water bath. Finally, the sample solution was added with $1 \mathrm{~mL}$ arsenomolibdat reagent and $7 \mathrm{~mL}$ of aquadest. The absorbance was recorded with a Hitachi U-2800 spectrophotometer at $520 \mathrm{~nm}$. The reducing sugar concentration was calculated based on the standard glucose curve (Wen et al., 2004).

Effect of $C / N$ ratio in fermentation medium containing molasses on PHB yield

The effects of various $\mathrm{C} / \mathrm{N}$ ratios $(5: 1,15: 1$ and 20:1) in the fermentation medium containing molasses on PHB production by Burkholderia sp B73 were observed during an incubation period of $72 \mathrm{~h}$. Molasses at various $\mathrm{C} / \mathrm{N}$ ratios $(5: 1,15: 1$ and 20:1) was added into fermentation medium for Burkholderia sp. B73 cultivation. The bacterial cells were collected for determination of PHB yield.

Effect of initial $\mathrm{pH}$ of fermentation media on $\mathrm{PHB}$ yield

The effect of initial $\mathrm{pH}$ on PHB production by Burkholderia sp $\mathrm{B} 73$ was evaluated in a fermentation medium containing molasses at a $\mathrm{C} / \mathrm{N}$ ratio of 20:1. The fermentation medium was adjusted to an initial $\mathrm{pH}$ of 7,8 and 9. The inoculum of Burkholderia sp. B73 was transferred to each Erlenmeyer flask and incubated at $30^{\circ} \mathrm{C}$ on a shaker incubator at $150 \mathrm{rpm}$ for $72 \mathrm{~h}$. The cells were collected for PHB yield.

\section{The Fourier transform infrared (FTIR) spectroscopy} analysis

The FT-IR spectrum was measured using Nicolet iS5 FTIR spectrometer (ThermoScientific Fisher, United States). The sample was scanned between a wavenumber range of 4000 to $400 \mathrm{~cm}^{-1}$ with 64 scans at a resolution of $2 \mathrm{~cm}^{-1}$.

\section{Statistical analysis}

The data were calculated as mean $\pm \operatorname{SD}(n=3)$ using the Microsoft Excel 2019 software. The treatment factors were molasses substrate at various $\mathrm{C} / \mathrm{N}$ ratios $5: 1 ; 15: 1 ; 20: 1$ (A1) and incubation time at 24,48 and $72 \mathrm{~h}(\mathrm{~B} 1)$. Each treatment was repeated three times to minimize experimental error. 


\section{Results and Discussion}

The by-product of agroindustry is a potential carbon source due to its high carbohydrate contents for microbial PHB production. Species of Burkholderia have been investigated for PHB production (Zhu et al., 2010; Pan et al., 2012). For the rapid confirmation of the potential Burkholderia sp. B73 as PHB-producing bacteria, Nile red staining was used in this experiment. We confirmed that Burkholderia sp. B73 was a PHB producer as suggested by pink color fluorescence under UV-light (Fig. 1A). Bacterial cells stained with Nile red staining were from the carbon-rich nutrient agar after 24 hours grown with colonies method. Then, the cells were observed under UV light $(235 \mathrm{~nm})$ showed pink colonies. As for PHB granules would be seen purple spots in the bacterial cells under a fluorescence microscope (400x) (Fig. 1B). The data have been accomplished in the previous research (Ratnaningrum et al., 2019). Therefore, Burkholderia sp. B73 was selected for further optimization of PHB production.
Prior to the investigation of the potential utilization of molasses as a carbon source for the growth of Burkholderia sp. B73, we analyzed the growth profiles of Burkholderia sp. B73 in NB medium. The Burkholderia sp. B73 growth profile was observed based on its optical density (OD) of $600 \mathrm{~nm}$ as a function of time. As can be seen in Figure 2, the growth of Burkholderia sp. B73 increased rapidly during the first $24 \mathrm{~h}$. The maximum $\mathrm{OD}_{600 \mathrm{~nm}}$ value was reached after 72 hours of incubation $\left(\mathrm{OD}_{600 \mathrm{~nm}}\right.$ of 2.095). It seems that the Burkholderia sp. B73 entered the stationary phase at 72 to $96 \mathrm{~h}$, the graph tending to decrease during this incubation period. A previous study reported Burkholderia sp. entered the stationary phase after ten $\mathrm{h}$ of incubation in NB medium (Khleifat et al., 2007). Our results were completely different from those of Khleifat $e t$ al. (2007); this may be due to the different species used during the study. Based on the growth curve profile of Burkholderia sp. B73, we, therefore, suggest that production of PHB began after $24 \mathrm{~h}$ of incubation.

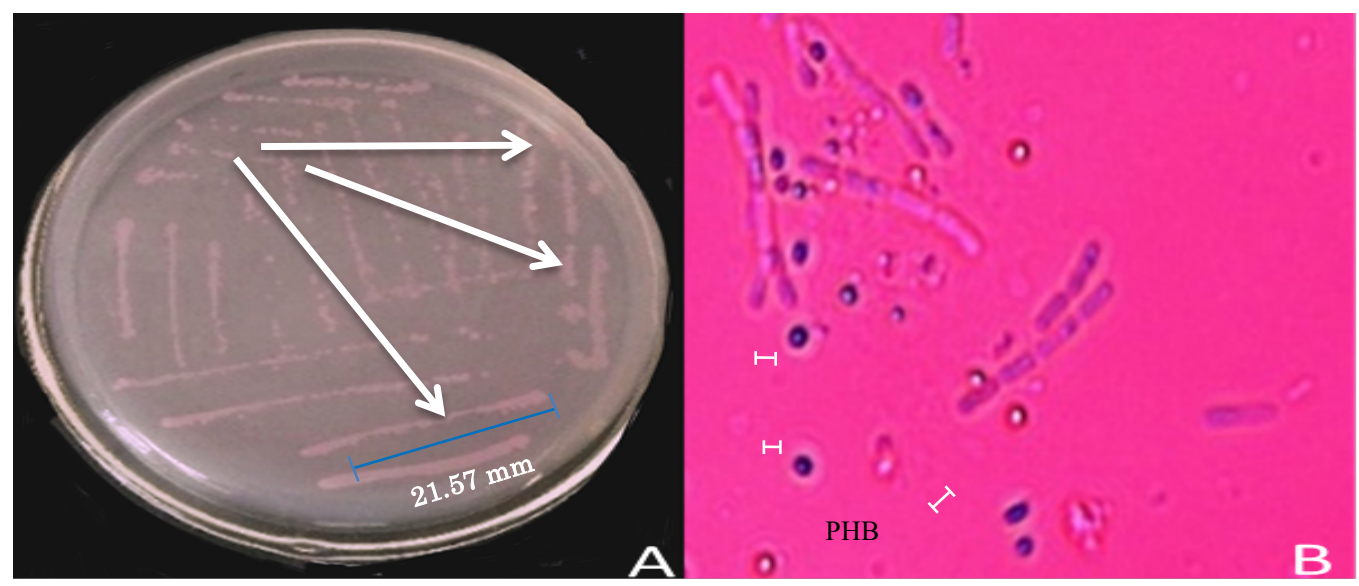

Figure 1. Burkholderia sp B73 cell stained with Nile red staining under UV light (A), PHB granule with stained Nile red (purple) under fluorescence microscope (400x)

Gambar 1. Burkholderia sp B73 diwarnai dengan pewarna Nile red di bawah lampu UV(A), Granul PHB dengan pewarna Nile red (ungu) di bawah mikroskop floresen (400x)

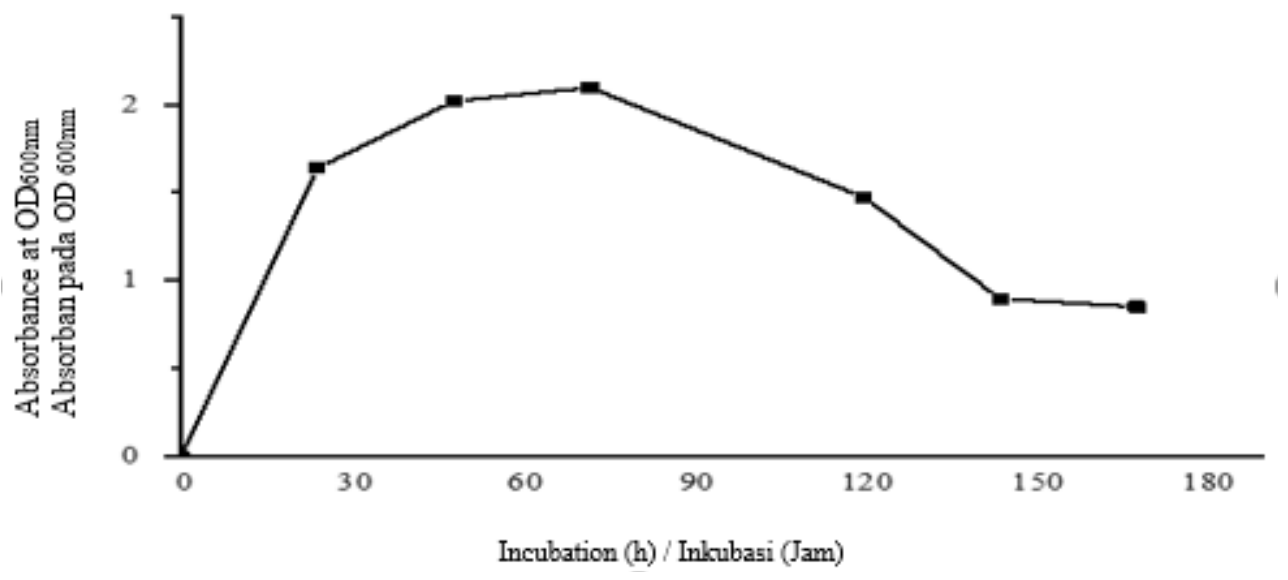

Figure 2. The growth curve of Burkholderia sp B37 in NB medium. The curve represents the absorbance and incubation period (h) at wave length $600 \mathrm{~nm}$

Gambar 2. Kurva pertumbuhan Burkholderia sp B73 dalam medium NB. Kurva menggambarkan absorbansi dan waktu inkubasi (jam) pada panjang gelombang $600 \mathrm{~nm}$ 
Effect of molasses on the growth of Burkholderia sp. B73

Considering the sugar-based materials of byproduct agroindustry that could be possibly used for microbial growth, molasses is a potential substrate for the growth of Burkholderia sp. B73. According to the growth profile of Burkholderia sp. B73 in the NB medium, we observed the effect of molasses as a carbon source for the growth of Burkholderia sp. B73 at 24, 36, and $72 \mathrm{~h}$ of incubation and $\mathrm{C} / \mathrm{N}$ ratios of $5: 1,15: 1$ and $20: 1$ with the initial concentration of carbon in molasses used for the growth of Burkholderia sp B73 with each $\mathrm{C} / \mathrm{N}$ ratios were 2,6 and $8 \mathrm{~g} \mathrm{~L}^{-1}$.

As shown in Figure 3A, at a $\mathrm{C} / \mathrm{N}$ ratio of $5: 1$, the DCW of Burkholderia sp B73 did not increase. A considerable increment of DCW was observed when the $\mathrm{C} / \mathrm{N}$ ratio of molasses was increased to 15:1 and 20:1 during 48 to $72 \mathrm{~h}$ of incubation. It seems that at a molasses $\mathrm{C} / \mathrm{N}$ ratio of $5: 1$, Burkholderia sp. B73 failed to grow due to the limited carbon concentration. A similar result was found when Ralstonia eutropha ATCC 17699 was fermented in corn step liquor at a $\mathrm{C} / \mathrm{N}$ ratio of 5:1.

Furthermore, it is noted that the critical glucose concentration for cell growth is $10 \mathrm{~g} \mathrm{~L} \mathrm{~L}^{-1}$ (Marangoni et al., 2001). Hence, we suggest that the minimum $\mathrm{C} / \mathrm{N}$ ratio of molasses for the growth of Burkholderia sp. B73 is 15:1. Atifah et al. (2007) reported that in a glucose concentration range of 10 to $40 \mathrm{~g} \mathrm{~L}^{-1}$, in general, the higher sugar concentration also higher of concentration Ralstonia eutropha cell during fermentation. Meanwhile, at a certain limit, a higher concentration of carbon and nitrogen with the same ratio will be more material that can be converted into the material building and cell reproduction. According to Gouda et al. (2007), the best of $B$. megaterium growth was obtained with $3 \%$ molasses, while the maximum got $2 \%$ and decreased when 5\% molasses. According to the several research previously reported, the finding strain Burkholderia sp B73 as PHA producer and using molasses as a carbon source is for the first time reported to date.

In this experiment, it appeared that the maximum value of DCW was observed after $72 \mathrm{~h}$ of incubation. By considering the DCW of Burkholderia sp. B73, the molasses as a carbon source should have been consumed. To confirm this, we evaluated the reducing sugar concentration of the fermentation medium containing molasses after inoculating with Burkholderia sp. B73. As shown in Figure $3 \mathrm{~B}$ at a $\mathrm{C} / \mathrm{N}$ ratio of $20: 1$ and $15: 1$, the reducing sugar concentration of the fermentation medium containing molasses showed a decreasing trend and entered the stationary phase after $48 \mathrm{~h}$.

In contrast, the fermentation medium containing molasses at a $\mathrm{C} / \mathrm{N}$ ratio of 5:1 had a flat curve. The calculations of sugar consumption of Burkholderia $\mathrm{sp}$. B73 suggests that at a $\mathrm{C} / \mathrm{N}$ ratio of 15:1 and 20:1, Burkholderia sp. B73 consumed about $55 \%$ of the sugar content, leaving about 6.68 and $8.85 \mathrm{~g} \mathrm{~L}^{-1}$ reducing sugar concentration after $72 \mathrm{~h}$ of incubation. These results are nearly similar to those from the study of Oliveira (1999), which showed that about $10 \mathrm{~g} \mathrm{~L}^{-1}$ of glucose still remains in the fermentation medium after inoculation with PHB-producing bacteria. Our study indicated that Burkholderia sp. B73 can utilize molasses for its growth.
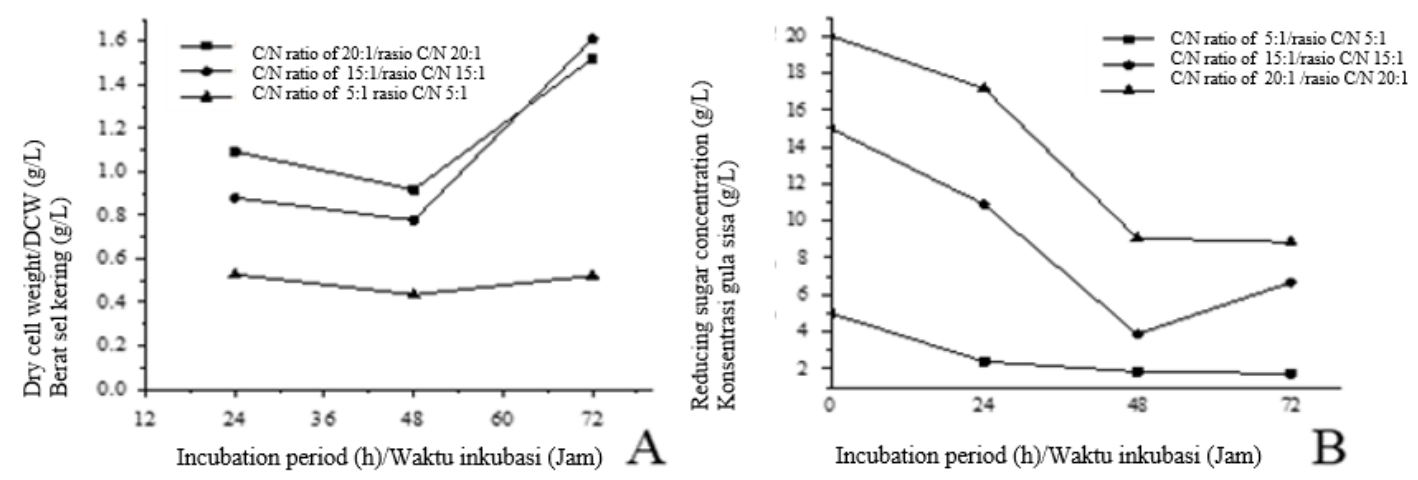

Figure 3. (A) The effect of different $\mathrm{C} / \mathrm{N}$ ratios $(5: 1 ; 15: 1$ and $20: 1)$ and incubation period (h) on dry cell weight of Burkholderia sp B73 $\left(\mathrm{g} \mathrm{L}^{-1}\right)$ and, (B) The effect of different $\mathrm{C} / \mathrm{N}$ ratio and incubation period $(\mathrm{h})$ on reducing sugar concentration $\left(\mathrm{g} \mathrm{L}^{-1}\right)$

Gambar 3. (A) Pengaruh perbedaan rasio C/N (5:1; 15:1 dan 20:1) dan waktu inkubasi (jam) terhadap berat sel kering Burkholderia sp B73 $\left(g L^{-1}\right)$ dan, (B) Pengaruh perbedaan rasio $C / N(5: 1 ; 15: 1$ dan 20:1) dan waktu inkubasi (jam) terhadap konsentrasi gula sisa $\left(g L^{-1}\right)$ 


\section{Effect of $C / N$ ratio of molasses in fermentation medium on PHB yield}

The key to PHB production lies on the availability and concentration of carbon. As a byproduct of the sugar industry, molasses is lucrative for PHB production. We have confirmed that the minimum $\mathrm{C} / \mathrm{N}$ ratio of molasses is required for the growth of Burkholderia sp. B73 is 15:1. However, this result did not reflect on the PHB yield. Thus, it is important to evaluate the PHB yield after extraction since PHB is accumulated intracellularly. As depicted in Figure 4A, at a 20:1 $\mathrm{C} / \mathrm{N}$ ratio of molasses in the fermentation medium, Burkholderia sp. B73 produced about $85 \%$ PHB but less at $\mathrm{C} / \mathrm{N}$ ratios of $5: 1$ and $15: 1$. It seems that at $\mathrm{C} / \mathrm{N}$ ratios of 5:1 and 15:1, Burkholderia sp. B73 uses molasses as a carbon source as a nutrient and energy, but not for PHB production (Sudesh et al., 2000). Therefore, we strongly suggest applying molasses at a $\mathrm{C} / \mathrm{N}$ ratio of 20:1 for PHB production.

\section{Effect of initial $\mathrm{pH}$ value on PHB yield}

Another important parameter that influences PHB production is the initial $\mathrm{pH}$ of the fermentation medium. In this research, we observed the effect of the initial $\mathrm{pH}$ value in the range of 7.0 to 9.0 towards $\mathrm{PHB}$ production by Burkholderia sp. B73 using molasses at a $\mathrm{C} / \mathrm{N}$ ratio of 20:1. As shown in Figure 4B, when the $\mathrm{pH}$ value of the molasses fermentation medium was adjusted to 8 and 9, the PHB yield tended to decrease. It is noted that the $\mathrm{pH}$ medium plays an important role in cell metabolism hence influencing the growth of bacteria. Saleem et al. (2014) recommended applying an initial $\mathrm{pH}$ in the range of 6.0 to 7.5 for microbial growth and PHB production (Saleem et al., 2014). Whereas, Irwandi et al. (2018) reported that at $\mathrm{pH}$ above 8.5 PHB producing bacteria did not grow well (Irwandi et al., 2018). Furthermore, PHB is decomposed in alkaline conditions ( $\mathrm{Yu}$ et $a l ., 2005)$. The data observed in this study were in agreement with these findings. Based on the maximum PHB produced, we suggest applying an initial $\mathrm{pH}$ of 7.0 for the optimum growth of Burkholderia sp B73 and PHB production.

It is important to note that the production of PHB by Burkholderia sp. B73 was $52.9 \%$ in Ramsay's minimal medium (Ratnaningrum et al., 2019). In this study, we reveal that the yield of PHB obtained by using molasses as substrate was two times higher. Molasses has been reported to contain high concentrations of carbohydrates, proteins, as well as micronutrients. The presence of carbohydrates and micronutrients supports the biosynthesis of PHB (Yüksekdağ et al., 2004). Therefore, molasses is very promising as a lowcost carbon source for enhancing the production of PHB.

\section{Characterization of $P H B$}

Finally, we characterized the polymer powder obtained by FTIR analysis to confirm PHB production. As depicted in Figure 5a, the FTIR spectrum of PHB extracted from Burkholderia sp. B73 shows peaks at $1722 \mathrm{~cm}^{-1}$ and $1288 \mathrm{~cm}^{-1}$ to $973 \mathrm{~cm}^{-1}$, corresponding to different functional groups in PHB. The peak at $1722 \mathrm{~cm}^{-1}$ corresponds $\mathrm{C}=\mathrm{O}$ stretch of the ester group (Hassan et al., 2016; Ratnaningrum et al., 2019). Whereas the peaks at $1288-973 \mathrm{~cm}^{-1}$ correspond to C-C, C-O, and C-H groups. Absorption bands recorded at 2956 and $2925 \mathrm{~cm}^{-1}$ indicate aliphatic $-\mathrm{CH}_{3}$ and $-\mathrm{CH}_{2}$ groups (Ratnaningrum et al., 2020). Bhagowati et al. (2015) reported that the FTIR spectrum of standard PHB shows peaks at a wavenumber of 1725 and $1288 \mathrm{~cm}^{-1}$, and it is strengthened by Pan et al. (2012) using Burkholderia cepacia ATCC17759 with sugar maple hemicellulose hydrolysate which analysis by NMR and physical-chemical characterization showed that PHA produced was identified as poly-hydroxybutyrate (PHB). These all peaks were similar to the characteristics of standard poly-hydroxybutyrate, as shown in Figure $5 b$.
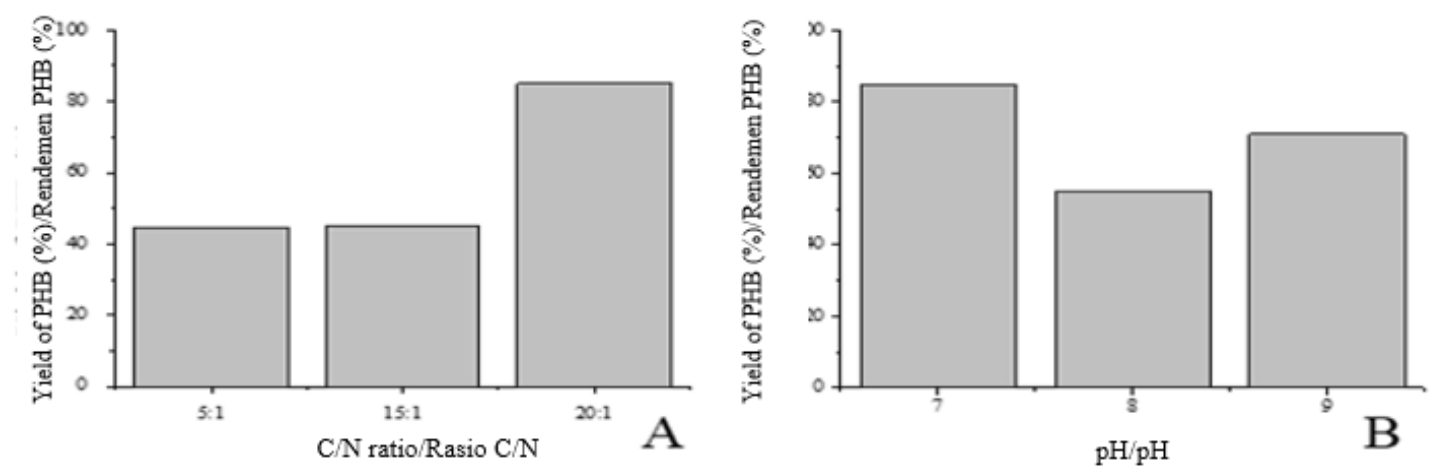

Figure 4. (A) PHB yield at different $\mathrm{C} / \mathrm{N}$ ratios after $72 \mathrm{~h}$ of incubation and (B) effect of initial $\mathrm{pH}$ value on $\mathrm{PHB}$ yield at $\mathrm{C} / \mathrm{N}$ ratio of $20: 1$ after $72 \mathrm{~h}$ of incubation

Gambar 4. (A) Rendemen PHB pada rasio C/N yang berbeda setelah inkubasi selama 72 jam dan (B) pengaruh $p H$ awal terhadap rendemen PHB pada rasio C/N 20:1 setelah inkubasi selama 72 jam 


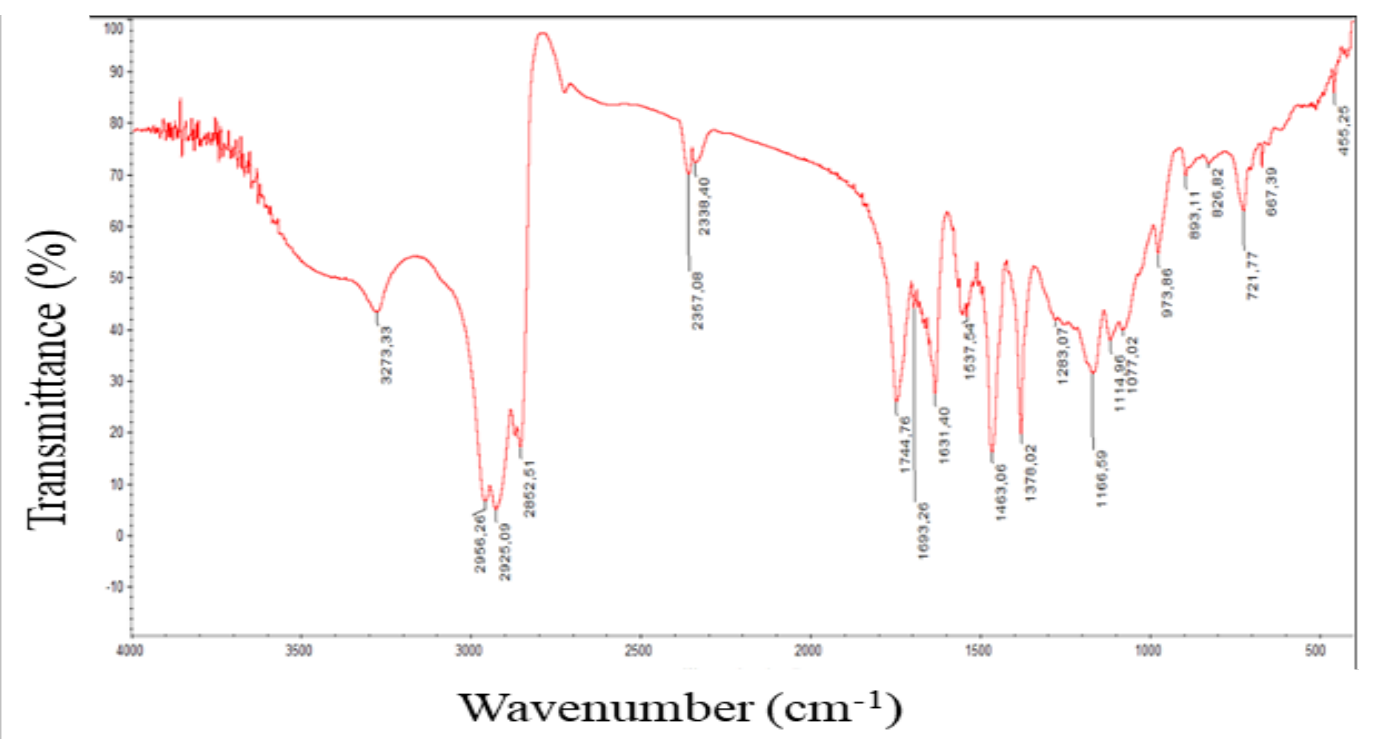

Figure 5a. FTIR spectrum of PHB extracted from Burkholderia sp. B73. The curve represents the transmittance (\%) and wavenumber $\left(\mathrm{cm}^{-1}\right)$

Gambar 5a. Spektrum FTIR PHB yang diekstraksi dari Burkholderia sp. B73. Kurva yang menggambarkan transmisi (\%) dan angka gelombang $\left(\mathrm{cm}^{-1}\right)$

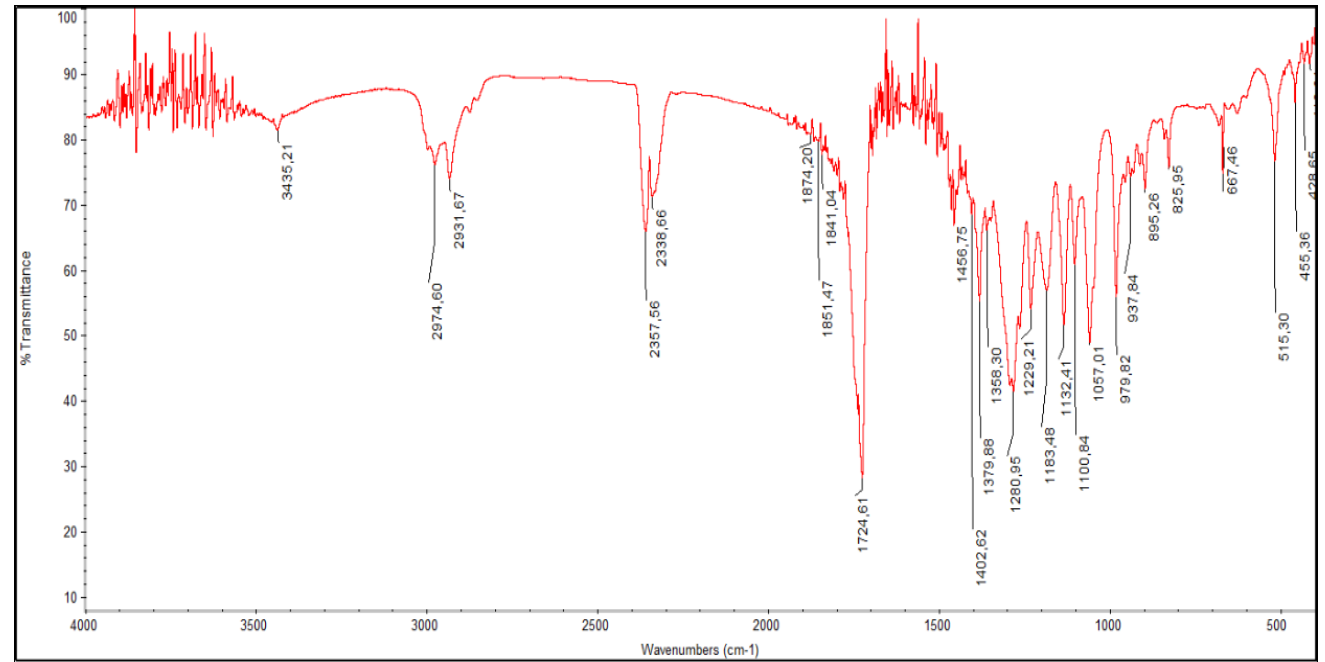

Figure 5b. FTIR standard spectrum of PHB. The curve represents the transmittance $(\%)$ and wavenumber $\left(\mathrm{cm}^{-1}\right)$ Gambar 5b. Spektrum standar FTIR PHB. Kurva menggambarkan transmisi (\%) dan angka gelombang $\left(\mathrm{cm}^{-1}\right)$

In this study, the FTIR spectrum of PHB produced by Burkholderia sp. B73 in fermentation medium containing molasses is very similar to previous reports, including PHB extracted from Bacillus drentensis BP17 (Jiun et al., 2010; Yuanzhen et al., 2014; Matias et al., 2016; Yamada et al., 2018; Zapata et al., 2019; Penkhrue et al., 2020). It has also been carried out from previous studies, thermal characteristics on the purified PHB granules extracted from Burkholderia sp B73 with TGA analysis (Ratnaningrum et al., 2019). The result obtained shows that at temperature of $63.5^{\circ} \mathrm{C}$ and $88.1^{\circ} \mathrm{C}$ there was a small weight loss, indicating the presence of volatile compounds and water and at temperature $293.3^{\circ} \mathrm{C}$, residual mass obtained below $0 \%$ were similar with standard
PHB (Lee et al., 2002). Hopefully, the purified PHB can be fully degraded without leaving any residues.

\section{Conclusion}

In summary, it was confirmed that molasses, an agro-industrial by-product easily available substrate, are cheap and can cut down the cost of PHB production. Based on the characteristics and the potency, these molasses can be used as a lowcost carbon source for PHB production by Burkholderia sp. B73. It is suggested to use molasses in fermentation medium at $\mathrm{C} / \mathrm{N}$ ratio 20:1, initial $\mathrm{pH} \mathrm{7,} \mathrm{and} 72 \mathrm{~h}$ of incubation for optimum PHB production by Burkholderia sp. B73 with PHB yield was $85 \%$. 


\section{Acknowledgements}

This work was supported by Mandiri Project. Authors thank to the Research Unit for Clean Technology, Indonesian Institutes Sciences for research facilities, e-layanan sains (e-ELSA), Indonesian Institute of Sciences for sample analysis, Research Center for Biotechnology, Indonesian Institute of Sciences for providing the bacteria, Mrs. Sri Pudjiraharti for delivering materials and Mr. Zybrand for proofreading the manuscript.

\section{References}

Accorsi R, A Cascini, S Cholette, R Manzini \& C Mora (2014). Economic and environmental assessment of reusable plastic containers: A food catering supply chain case study. Intl $J$ of Production Economics 152, 88-101.

Aramvash A, ZF Moazzeni \& BN Gholami (2018). Comparison of different solvents for extraction of polyhydroxybutyrate from Cupriavidus necator. Eng in Life Sci 18, 20-28.

Ashraf S, S Ali S \& H Ikramul (2015). Pretreatment of raw sugarcane molasses by metal complexing agents for improved citric acid fermentation by Aspergillus niger. Intl J Res in Pharm Biosci 2(6), 34-40.

Atifah N, S Khawar \& A Suryani (2007). Kajian fermentasi bioplastik poli-(3Hidroksialkanoat)/PHA oleh Ralstonia etropha menggunakan sumber karbon hidrolisat pati sagu. Jurnal Teknologi Pertanian 8(3), 160171

Beaulieu M, Y Beaulieu, J Melinard, S Pandian \& J Goulet (1995). Influence of ammonium salts and cane molasses on growth of Alcaligenes eutrophus and production of polyhydroxybutyrate. Appl Environ Microbiol 61(1), 165-169.

Bhagowati P, S Pradhan, HR Dash \&S Das (2015). Production, optimization and characterization of polyhydroxybutyrate, a biodegradable plastic by Bacillus spp. Biosci Biotechnol Biochem 79, 1454-63

Bhuwal, Anish K, G Singh, NK Aggarwal, V Goyal \& A Yadav (2013). Isolation and screening of polyhydroxyalkanoates producing bacteria from pulp, paper, and cardboard industry wastes. International J Biomaterials. DOI: $10.1155 / 2013 / 752821$.

Botha T \& H von Blottnitz (2006). A comparison of the environmental benefits of bagassederived electricity and fuel ethanol on a lifecycle basis. Energy Policy 34(17), 2654-2661.

Chauhan MK, Varun, S Chaudhary S, S Kumar \& Samarm (2011). Life cycle assessment of sugar industry: A review. Renewable and Sustainable
Energy Reviewers. DOI: 10.1016/j.rser.2011.04.033.

Choi J \& S Lee (1999). Factors affecting the economics of polyhydroxyalkanoate production by bacterial fermentation. Appl Microbiol Biotechnol 51, 13-21.

Gomaa EZ (2014). Production of polyhydroxyalkanoates (PHAs) by Bacillus subtilis and Escherichia coli grown on cane molasses fortified with ethanol. Braz Arch Biol and Technol 57(1), 145-154.

Gouda MK, ES Azza \& HO Sanaa (2001). Production of PHB by a Bacillus megaterium strain using sugarcane molasses and corn steep liquor as sole carbon and nitrogen sources. Microbiol Res 156, 201-207.

Hassan MA, KB Elsayed, GA Salah \& RH Hussien (2016). Production and characterization of polyhydroxybutyrate (PHB) produced by Bacillus sp. isolated from Egypt. J Applied Pharmaceutical Sci 6 (4), 46-51. DOI: 10.7324/JAPS.2016.60406

Irwandi, A Djamaan \& A Agustien (2018). Pengaruh konsentrasi minyak kelapa sawit mentah terhadap jumlah biomassa bakteri Baciluss spp. penghasil polimer poli (3hidroksibutirat). Scientia Jurnal Farmasi dan Kesehatan 8(1), 64-72

Jiun YC, Y Tan, MR Samian \& K Sudesh (2010). Isolation and characterization of Burkholderia $s p$. USM (JCM15050) capable of producing polyhydroxyalkanoate (PHA) from triglycerides, fatty acids and glycerols. J Polym Environ 18,584-592. DOI 10.1007/s10924010-0204-1

Kamravamanesh D, M Lackner \& C Herwig (2018). Bioprocess engineering aspects of sustainable polyhydroxyalkanoate production in cyanobacteria. Bioeng (Basel) 5(4), 111.

Khleifat K (2007). Effect of substrate adaptation, carbon starvation and cell density on the biodegradation. of phenol by Actinobacillus sp. Fresenius Environ Bull 16, 726-730.

Koller M (2017). Advances in polyhydroxyalkanoate (PHA) production. Bioengineering (Basel) 4(4), 88.

Kresnawaty I, AS Mulyatni, DD Eris \& HT Prakoso (2016). Characterization of PHA produced by Pseudomonas aeruginosa and Bacillus subtilis inoculated in palm oil mill effluent (POME) media. Menara Perkebunan 82(2), 57-63.

Lee SN, YL Moon \& WH Park (2002). Thermal stabilization of poly(3-hydroxybutyrate) by poly(glycidyl methacrylate) J Appl Polym Sci. 83 2945-52 
Luo, C Rong, LW Yun \& EN Mohamed (2014). The Industrial Production of PHA. In Polyhydroxyalkanoates (PHAs): Biosynthesis, Industrial Production and Applications in Medicine. Chapter 13. Nanotechnology Science \& Technology Inc. New York 117883619, USA

Marangoni C, A Furigo Jr \& Aragão GMF (2001). The influence of substrate source on the growth of Ralstonia eutropha, aiming at the production of polyhydroxy alkanoate. Braz J Chem Eng 18(2), 175-180.

Matias F, CA Brandt, ES de Silva \& MF de Adrade Rodrigues (2017). Polyhydroxybutyrate and polyhydroxydodecanoate produced by Burkholderia contaminans IPT553. J Appl Microbiol 123 (1),124-133.

Mostafa NA, AA Farag, HM Abodief \& AM Tayeb (2018). Production of biodegradable plastic from agricultural wastes. Arab J Chem 11(4), 546-553.

Naheed N \& Jamil N (2014). Optimization of biodegradable plastic production on sugar cane molasses in Enterobacter sp. SEL2. Braz J Microbiol 45(2), 417-426.

Oliveira FC, MGF Denisse \& L Castilho (1999). Production of poly(3-hydroxybutyrate) by solid-state fermentation with Ralstonia eutropha. Biotechnol Letters 26 (24): 1851-5. DOI:10.1007/s10529-004-5315-0

Pan W, JA Perrotta, AJ Stipanovic, CT Nomura \& JP Nakas (2012). Production of polyhydroxyalkanoates by Burkholderia cepacia ATCC 17759 using a detoxified sugar maple hemicellulosic hydrolysate. $J$ Ind Microbiol and Biotech 39(3), 459-469.

Penkhrue W, D Jendrossek, C Khanongnuch, AW Pathom, T Aizawa, RL Behrens \& S Lumyong (2020). Response surface method for polyhydroxybutyrate (PHB) bioplastic accumulation in Bacillus drentensis BP17 using pineapple peel. PLoS One 15(3): e 0230443.

Ratnaningrum D, Een SE, Akbar HDA, Vienna S, Puspita L, Eva Frasnawaty \& Sri P (2020). The effect of inoculum and glucose addition of polyhydroxyalkanoate production by Brevibacterium sp. B45. Menara Perkebunan 89 (1), 1-7.

Ratnaningrum D, V Saraswaty, S Priatni, Puspita L, A Purnomo \& S Pudjiraharti (2019). Screening of polyhydroxyalkanoates (PHA)producing bacteria from soil bacteria strains. IOP Conf. Series: Earth and Environmental Science 277.
Saleem, Faiza, Reema A, Yasar S, Shagufta N, Q Syed, Syed Q, N Munir, Nazia K \& Abdul RK (2014). Analysis and evaluation of growth parameters for optimum production of polyhydroxybutyrate (PHB) by Bacillus thuringiensis strain CMBL-BT-6. Pak J Zoo 46(5), 1337-1344

Senthilkumar S, T Suganya, K Deepa, J Muralidharan \& K Sasikala (2016). Supplementation of molasses in livestock feed. International J Sci, Environ Technol 5 (3), 1243 - 1250. ISSN 2278-3687

Spiekerman P Rehm B, RBD Kalscheuer \& A Steinbüchel (1999). A sensitive, viable-colony staining method using Nile red for direct screening of bacteria that accumulate polyhydroxyalkanoic acids and other lipid storage compounds. Arch Microbiol 171, 7380.

Sudesh K, H Abe \& Y Doi (2000). Synthesis, structure and properties of Polyhydroxyalkanoates: biological polyesters. Prog in Polymer Sci 25, 1503-1555.

Webb HK, ARJC Jaims \& PI Elena (2013). Plastic degradation and its environmental implications with special reference to poly(ethylene terephthalate). Polymers 5, 1-18.

Wen Z, L Wei \& CH Shulin (2004). Hydrolysis of animal manure lignocellulosics for reducing sugar production. Biores Technol 91(1), 31-39.

Wu Q, H Huang, G Hu, J Chen, KP Ho \& GQ Chen (2001). Production of poly-3-hydroxybutrate by Bacillus Sp. JMa5 cultivated in molasses media. Antonie van Leeuwenhoek, International J General and Mol Microbiol 80, 111-118. DOI: 10.1023/A:1012222625201.

Yamada M, A Yukita, Y Hanazumi, Y Yamahata, H Moroju, M Miyaki, T Yamasha \& Histoshi S (2018). Poly(3-hydroxybutyrate) production using mannitol as a sole carbon source by Burkholderia sp. AIU M5M02 isolated from a marine environment. J Fisheries Sci. DOI: 10.1007/S1256-017-1164-3

Yan D, Y Lu, YF Chen \& Q Wu (2011). Waste molasses alone displaces glucose-based medium for microalgal fermentation towards cost-saving biodiesel production. Biores Technol 102(11), 6487-6493.

Yu J, D Plackett \& LXL Chen (2005). Kinetics and mechanism of the monomeric products from abiotic hydrolysis of poly[(R)-3hydroxybutyrate] under acidic and alkaline conditions. Pol Deg and Stab 89, 289-299. 
Yüksekdağ ZN, B Aslim, Y Beyatli \& N Mercan (2004). Effect of carbon and nitrogen sources and incubation times on poly-betahydroxybutyrate (PHB) synthesis by Bacillus subtilis 25 and Bacillus megaterium 12. Afr J Biotech 3(1), 63-66

Zapata WA, AA Cárdenas \& FV Restrep Andrés (2019). Evaluation of polyhydroxyalkanoate (PHAs) production with a bacterial isolate using cassava flour hydrolysates as an alternative substrate. DYNA 86(208), 75-81

Zhu C, TN Christopher, JA Perrotta, JS Arthur \& PN James (2010). Production and characterization of poly-3-hydroxybutyrate from biodiesel-glycerol by Burkholderia cepacia ATCC 17759. Biotechnol Progress 26(2), 424-430. DOI: 10.1002/btpr.355. 